\title{
Ownership mode, cultural distance, and the extent of parent firms' strategic control over subsidiaries in the PRC
}

\author{
Jonas Puck ${ }^{1}$ • Markus K. Hödl ${ }^{1}$. \\ Igor Filatotchev ${ }^{1,2} \cdot$ Hans-Georg Wolff ${ }^{3}$. \\ Benjamin Bader ${ }^{4}$
}

(C) The Author(s) 2016. This article is published with open access at Springerlink.com

\begin{abstract}
Previous studies often associated a specific type of ownership mode with the extent of control a parent firm may have over (strategic) decision-making in a foreign subsidiary, suggesting that parent firms should have higher control over wholly-owned subsidiaries (WoS) than international joint ventures (IJVs). Building on principal agent theory, we argue that in the Chinese context higher ownership levels do not necessarily have a positive effect on the extent of control over the foreign subsidiary. We further argue that cultural distance between the parent firm and the subsidiary moderates this relationship. We test our hypotheses using data from a sample of 156 foreign subsidiaries in the People's Republic of China (PRC) and find strong support for our arguments. Our findings show that in WoS parent firms reduce their extent of control, while in IJVs parent firms increase their extent of control. Moreover, we find that extent of control over WoS (IJVs) declines (increases) when cultural distance increases. Our results have significant theoretical implications for international business (IB) research as they challenge existing views with regard to the relationship between ownership mode and control as well as the moderating effect of cultural distance.
\end{abstract}

Jonas Puck

jonas.puck@wu.ac.at

1 Institute for International Business, WU Vienna, Welthandelsplatz 1, 1020 Vienna, Austria

2 Cass Business School, 106 Bunhill Row, London EC1YY 8TZ, UK

3 Department of Psychology, University of Cologne, Bernhard-Feilchenfeld-Str. 11, 50969 Cologne, Germany

4 Institute for Strategic Management and Organization, Leuphana University Luneburg, Scharnhorststr.1, 21335 Lüneburg, Germany 
Keywords Ownership mode $\cdot$ Cultural distance $\cdot$ Control $\cdot$ Subsidiaries

Multinational corporations (MNCs) have long faced challenges associated with balancing the needs to control strategic decision-making of their subsidiaries in the far-flung foreign markets on the one hand, and pressures for local adaption to the specific institutional and economic characteristics of culturally distant locations on the other (Doz \& Prahalad, 1984). Previous studies have analyzed these complex relationships between a parent firm and its foreign subsidiary focusing on the level of control the former exerts over the latter in the context of entry mode research (Anderson \& Gatignon, 1986; Hill, Hwang, \& Kim, 1990), subsidiary mandate (Birkinshaw, Hood, \& Jonsson, 1998; Cray, 1984; Doz \& Prahalad, 1981; Garnier, 1982; Gates \& Egelhoff, 1986), or expatriate management (Kobrin, 1988) research streams. Specifically, the level of control has been viewed as a means of coordinating globally dispersed units within the MNC (Gates \& Egelhoff, 1986), aligning subsidiary behavior with corporate objectives (O'Donnell, 2000), and mitigating uncertainty in culturally distant locations (Garnier, 1982). However, there are still significant theoretical and empirical gaps in our understanding of the complex inter-relationship between the parent firm's choice of ownership mode and the extent of its control over a subsidiary. More specifically, little is known about how this inter-relationship is affected by cultural distance between the parent firm and its subsidiary.

Previous research has extensively investigated the level of control that different ownership modes provide the parent firm over their foreign subsidiaries (Anderson \& Gatignon, 1986; Kim \& Hwang, 1992; Padmanabhan \& Cho, 1996). Most of these studies (Anderson \& Gatignon, 1986; Kim \& Hwang, 1992) directly associate the ownership mode with the actual extent of control (for notable exceptions, see Brouthers \& Hennart, 2007). Hill et al. (1990: 118) maintained, for instance, that "different entry modes imply a different level of control over the foreign operation." Furthermore, they argued that for joint ventures, "the level of control will fall somewhere between that consistent with licensing and that consistent with a wholly owned subsidiary" (Hill et al., 1990: 118). Overall, studies thus seem to assume that legal authority is equivalent to the actual extent of control exercised in a parent-subsidiary relationship. We challenge this notion under certain conditions. For example, research on "subsidiary mandate" clearly indicates that even within the same type of ownership modes, parent firms may have varying levels of control over foreign subsidiaries, depending, for example, on their contribution of firm-specific assets (Birkinshaw et al., 1998) or the type of mandate they develop within the global MNC network (Birkinshaw \& Morrison, 1995). These scholars identify determinants of operational control (or autonomy) in foreign subsidiaries and acknowledge that subsidiaries differ in terms of their extent of control; however, they do not take the type of ownership mode into account.

We build on this research and distinguish between ownership mode and the actual extent of control. Following the suggestions of Geringer and Hebert (1989) we focus on the extent of control and define it as the extent of decision-making that actually takes place at the parent firm (in our case: the foreign parent firm). Specifically, we use a combination of what Geringer and Hebert (1989) call the "extent of control" and the 
"focus of control" as we analyze the extent of control with a focus on control dimensions. ${ }^{1}$ In line with their reasoning, we view these types of control as complementary and interdependent. By grounding our study within the principal agent theory ${ }^{2}$ (Jensen \& Meckling, 1976), we argue that ownership mode and extent of control are not equivalent, as the ownership mode only determines the contractual relation between the parent firm and the foreign subsidiary (i.e., the potential structure of a decisionmaking hierarchy), but not the actual extent of control parent firms exercise over the decision-making process in their subsidiaries. This assumption is in line with existing research that argues that control "is a much more subtle phenomenon (...) and it can be quite distinct from mere consideration of relative equity ownership" (Geringer \& Hebert, 1989: 240-241). In a similar vein, Filatotchev and Wright (2011: 478) contended that "dominant ownership may not bring control in certain host country environments and minority equity holders may have effective control of certain activities within an IJV." Surprisingly, empirical evidence on this important relationship is still lacking.

In addition, we investigate whether the relationship between the ownership mode and the extent of control over foreign subsidiaries is dependent on the contextual environment. We take into account cultural distance between the parent firm and foreign subsidiary, suggesting that cultural distance is a source of uncertainty that affects the relationship between the type of ownership mode and the extent of control. By building on research by Wilkinson, Peng, Brouthers, and Beamish (2008) and Hamilton and Kashlak (1999), among others, we make a further theoretical advance by arguing that cultural distance may influence the effect of ownership mode on the level of control. More specifically, we develop theoretical arguments and provide empirical tests showing a moderating effect.

We focus on foreign subsidiaries in the People's Republic of China (PRC). With more than US\$95 billion in inward FDI in 2009 (UNCTAD, 2011), during the time of data sampling, the country was one of the largest recipients of FDI globally. Moreover, according to the statistics of MOFCOM (2010) wholly-owned subsidiaries (WoS) and international joint ventures (IJVs) are the dominant ownership modes in China (Puck, Holtbrügge, \& Mohr, 2009). Therefore, we focus on these two types of ownership modes in our analysis. Given that FDI in China involves investors from countries exhibiting high variation in cultural distance to China, we believe that this country provides a valuable setting for analyzing the moderating effect of cultural distance.

We make a number of theoretical contributions to the literature. First, we build on principal agent research and show that the extent of control exerted over foreign subsidiaries can substantially differ from the ownership mode, that is, the level of internalization within the Williamson (1973) market-hierarchy continuum. Doing so is an important contribution, since our study advances literature by integrating agency theory and internationalization research in the context of subsidiaries operating in China. Second, we argue that cultural distance increases the level of uncertainty and thus the agency problems between the parent firm and the foreign subsidiary, moderating the

\footnotetext{
${ }^{1}$ Please note that we do not aim at investigating organizational mechanisms of control (Chang \& Taylor, 1999; Eisenhardt, 1989; Geringer \& Hebert, 1989; Ouchi \& Maguire, 1975). Rather the objective of our study is to investigate the level of integration in headquarters-subsidiary relations.

${ }^{2}$ We would like to thank one of the anonymous reviewers for highlighting the fit of principal agent theory to our research question.
} 
relationship between ownership mode choice and actual extent of control. In this respect, we view cultural distance as a source of uncertainty and argue that ownership modes are associated with different types of uncertainty. This particular view is novel and enhances literature by overcoming the relatively generalized notion that the extent of exercised control is universal. With our study we account for the cultural context in this regard, showing that there is a different effect of the relationship between control and entry mode, depending how culturally different the headquarters (HQ) home country and the host country, in our case China, are. Finally, while most research has analyzed subsidiaries in developed countries (Cleeve, 1997; Hennart, 1991; Kogut \& Singh, 1988), we conduct our analysis in an emerging market, the PRC. In the emerging market context, uncertainties associated with doing business in a culturally distant environment are particularly significant. Focusing on this host country advances literature since it also accounts for regional context, while at the same time controlling for cultural influence. We expect that China represents an important research laboratory to empirically explore our theoretical propositions.

This study is organized as follows. In the next section, we present our theoretical framework and conceptualize our main theoretical constructs. In the following section, we derive hypotheses about the effect of ownership mode choice on the actual extent of strategic control. This is followed by arguments related to the moderating effect of cultural distance. The ensuing section presents our sample and measures followed by a discussion of our empirical results. The final section outlines implications and limitations of our research.

\section{Theoretical framework and conceptualization}

Filatotchev and Wright (2011) argued that issues related to strategic controls in international business (IB) have a strong behavioral dimension, and this is a focal point of agency-grounded research. Following research by Chang and Taylor (1999), O’Donnell (2000), Johnson, Cullen, Sakano, and Bronson (2001), and Roth and O'Donnell (1996), among others, we build on agency theory to describe the relationship between the parent firm and the foreign subsidiary management. For the purpose of our study, the parent firm represents the principal, while the management of the foreign subsidiary represents the agent. Therefore, a potential agency conflict is associated with goal incongruence between the parent firm and subsidiary management, especially when it is difficult for the parent firm to monitor the subsidiary's actions (O'Donnell, 2000). For example, Chang and Taylor (1999) argued that the HQsubsidiary relationships can be explained in terms of agency theory because the parent firm expects the subsidiary management to work on its behalf in return for the resources and competences it transfers abroad. In a similar vein, Roth and O'Donnell (1996: 680) suggested that HQ-subsidiary relationships fit well agency framework as "headquarters delegates work and responsibilities to foreign subsidiaries."

Within agency framework, the ownership mode of foreign subsidiaries determines the contractual relation between the parent firm (i.e., the principal) and the foreign subsidiary (i.e., the agent) (Yan \& Gray, 2001b). Moreover, this choice defines the potential extent of managerial hierarchy and associated cash-flow rights of investors in a foreign subsidiary. We focus on two typical types of ownership modes in foreign 
markets: IJVs and WoS. As control serves as a means of solving agency problems, the actual extent of control parent firms exert over the foreign subsidiary management is another key dimension of governance. Therefore, the extent of control parent firms exert over foreign subsidiaries is a means of aligning subsidiary behavior with parent firm's corporate objectives (O'Donnell, 2000).

We follow Geringer and Hebert (1989) and focus on the extent of control, defining it as the extent of decision-making that actually takes place at the parent firm in areas such as strategic decisions, R\&D investment, production, distribution, budget responsibility, and adjustment to local requirements. However, in contrast to Geringer and Hebert (1989), we do not look at the dimensions of control per se but rather focus on the actual extent of control that is executed. In other words, what we analyze is the question, how much of its control power the parent firm as a principal theoretically has actually uses to align its agent. While scholars such as Brenner and Ambos (2013) or Sitkin and George (2005) provided in-depth assessment of the means by which HQ control and show that control can be exerted differently depending on the company's goals, we exclusively focus on the extent of control as perceived by the subsidiary manager.

Within agency research, uncertainty surrounding the decision-making process is considered a key driver of potential agency conflicts. According to past research, this uncertainty is substantially influenced by cultural distance (Roth \& O'Donnell, 1996), and, therefore, cultural distance may be a source of potential and actual agency problems. Specifically, we suggest that cultural distance is a source of uncertainty since it complicates the verification of claims of subsidiary agents. Roth and O'Donnell (1996), for instance, used cultural distance in the context of HQ-subsidiary relationships and reported that cultural distance aggravates agency problems as it increases information asymmetry between the parent firm and the foreign subsidiary. We define cultural distance in line with past research as the differences in social norms and values between the home and the host country (Hofstede, 1980) and conceptualize it as a moderator in the relationship between ownership mode choice and actual extent of control.

When taking this perspective, it is also necessary to consider the institutional environment. Institutional theory differentiates between normative, cognitive, and regulative pillars of the institutional environment (Bruton, Ahlstrom, \& Li, 2010a; Scott, 1995). While the normative and cognitive pillars are often conceptualized and measured as cultural distance, ${ }^{3}$ the regulative pillar is often associated with formal dimensions such as political and economic distances (Campbell, Eden, \& Miller, 2012; Jensen \& Szulanski, 2004; Schwens, Eiche, \& Kabst, 2011; Yiu \& Makino, 2002). Salomon and $\mathrm{Wu}$ (2012: 350) maintained that "institutional distance is the extent of difference between two countries in terms of its institutional context, expressed on cultural, economic, political, and regulatory dimensions." In addition to these distance types, scholars argue that geographic distance may influence internationalization strategies (Fladmoe-Lindquist \& Jacque, 1995; Fratianni \& Chang Hoon, 2009). Finally, previous studies also indicate that these types of distances (cultural, political, economic, and

\footnotetext{
3 There is considerable debate in the literature about the conceptualization of the cognitive pillar (Bruton et al., 2010a; Xu \& Shenkar, 2002). We follow the suggestions of Jensen and Szulanski (2004) and Salomon and Wu (2012), among others, who argue that cultural distance captures both normative and cognitive dimensions.
} 
geographic) are most commonly used by IB research analyzing the effect of distance on internationalization decisions (for a review, see Berry, Guillén, \& Nan, 2010).

In our analysis, we have chosen to focus on cultural distance for a number of theoretical reasons. First and foremost, we assume that informal differences in cultural distance have a strong effect on the relationship between ownership mode and extent of control. Compared to formal differences, like the legal rules of the system, these informal differences are relatively hard to observe. In contrast, written rules (e.g., constitution, laws) can be quite easily understood by everyone (Scott, 1995). From a theoretical point of view, we contend that new media and new technologies nowadays make it easier for parent firms to install control mechanisms even across long physical distances. However, cultural distance is an informal phenomenon that still needs to be taken into account in detail.

Cultural differences are deeply embedded in social norms, beliefs, and values. Many aspects of culture can hardly be codified or directly observed (Yiu \& Makino, 2002). Therefore, foreign subsidiaries may find it difficult to deal with cultural difference, which poses quite some challenges. In a similar vein, Gaur and Lu (2007) noted that foreign subsidiaries can easily obtain information about formal differences by drawing on secondary information. However, informal differences are rooted in the social environment and are thus harder to grasp and interpret by foreigners (Demirbag, Glaister, \& Tatoglu, 2007). In addition, they are strongly related to the individuals involved, hence they will never be completely solved as they re-occur with every new generation of staff involved. From the agency perspective, cultural distance may therefore have a strong effect on uncertainty and, as a result, it contributes substantially to the level of agency costs.

Finally, we clearly focus on cultural distance as a source of uncertainty (Slangen \& van Tulder, 2009) since it complicates the verification of claims of both external (e.g., customers, suppliers, partners) and internal (e.g., employees) stakeholders. Moreover, Lee, Shenkar, and Li (2008: 1117) emphasized that scholars have insufficiently differentiated between the "challenge of working in a foreign environment" and the "challenge of working with a foreign partner," which is reflected in our differentiation between just working in such foreign environment (WoS) and also working with a foreign partner (IJV). Therefore, cultural distance should have a significant impact on the extent of actual or anticipated agency conflicts between parent firms and their subsidiaries in different countries, and this should have a profound impact on the relationship between ownership mode and the extent of control parent firms exercise over their subsidiaries. In the following sections, we develop these arguments further and suggest testable hypotheses.

\section{Hypotheses development}

\section{Ownership mode and extent of control}

Within the agency framework, an ownership mode associated with a foreign subsidiary defines the contractual relationship between the parent firm (i.e., the principal) and the foreign subsidiary (i.e., the agent) (Yan \& Gray, 2001b). While WoS represent contracts with a clear principal-agent relationship, IJVs represent contracts with more interest 
groups, that is, the actual subsidiary as well as the partner firm. Therefore, the principalagent relationship is more complex and in terms of exerting control, differences may arise. We focus on these two types of ownership modes in foreign markets and argue that the different contractual arrangements underlying these modes have different implications for the level of agency costs and, as a result, for the extent of control a parent would want to engage to minimize these costs. Again, in this study we define extent of control as the extent of decision-making that actually takes place at the parent firm (in our case: the foreign parent firm).

The complexity of the contractual relationship and associated agency conflicts considerably differs between these two ownership modes, with the complexity of the relationship between parent firms and IJVs being higher than between parent firms and WoS. ${ }^{4}$ IJVs represent contractual relations in which two or more parent firms share ownership and control rights over the combined resources to accomplish goals they cannot accomplish on their own. WoS, on the other hand, represent contracts that grant the parent firm ownership and associated residual claim rights over the foreign subsidiary's assets and profits (Puck et al., 2009). Yan and Gray (2001b: 303) referred to an IJV as "incomplete contract in which the partners have to live with substantial uncertainties down the road." These factors suggest that WoS and IJVs may suffer from different types of agency conflicts. WoS represent a classic case of a parent firm needing to monitor and restrain managerial opportunism on the subsidiary level. The situation for IJVs is more complex since they may suffer from what more recent research describes as a "multiple agency" conflict (Arthurs, Hoskisson, Busenitz, \& Johnson, 2008; Bruton, Filatotchev, Chahine, \& Wright, 2010b). Managers in an IJV are agents to at least two principals in a venture (e.g., foreign and local co-investors). The principals may have different goals and objectives, diverse decision-making horizons, and strategic priorities. As a result, managers have to reconcile the objectives of multiple principals.

Building on this research, we suggest that the shared arrangement in IJVs and, in particular, the idiosyncratic commitment of resources, complicate the ability of parent firms to observe and evaluate how these resources are deployed in foreign markets compared to the arrangements in WoS (Johnson et al., 2001). Parent firms operating IJVs thus often find it more difficult to assess whether the competences and resources transferred abroad yield their highest productive value compared to their counterparts operating WoS. Combs and Ketchen (1999: 870), for instance, maintained that while equity stakes may generally mitigate monitoring costs, IJVs nevertheless expose parent firms to agency-related control problems since partners may have "incentives to shirk" by holding back inputs at the expense of the IJV. In a similar vein, Reuer and Miller (1997: 426) argued that in IJVs agency hazards may occur "due to coordination problems arising from shared ownership and control." In WoS, by contrast, the direct, unilateral chain of command facilitates the monitoring of deployed resources and competences and thus enhances control options. Therefore, we expect that the joint management of foreign operations increases the level of agency costs for parent firms, leading to higher agency costs for firms operating IJVs than for their counterparts operating WoS.

\footnotetext{
${ }^{4}$ While the complexity may be higher in the sense that there are two parents instead of one, the reason for complexity may not all be about divergence in motives and goals.
} 
In addition, involvement of a third party in IJVs increases the ambiguity surrounding the actions and behavior of subsidiary management abroad compared to WoS, further aggravating problems associated with information asymmetry. For parent firms, it often becomes difficult to process information from IJV management and subsequently devise and implement corporate strategies. Furthermore, ambiguity stemming from third-party (i.e., the joint venture partner) involvement complicates the ability of firms to align subsidiary managers' actions and behavior with corporate objectives. In IJVs, this increase in information asymmetry may provide scope for managerial opportunism and suboptimal decision-making (Johnson et al., 2001). This ambiguity may enhance the likelihood of goal incongruence and managerial conflicts more substantially in IJVs than in WoS given that the integration of diverse management approaches may hamper IJV operations. In WoS, in contrast, the transfer and implementation of management practices are less difficult and costly given the increased possibilities of directly supervising and commanding subsidiary management. From an agency theory perspective, this ambiguity increases the information deficit for parent firms, leading to a higher information asymmetry and agency costs between parent firms and IJVs than between parent firms and WoS. Ott (2005: 67) contended that "the triangular structure" in IJVs contributes to an information problem. Overall, we contend that the complexity of the contractual relationship and ambiguity of subsidiary managers' actions and behavior (that stem from the joint management of foreign operations) entail higher agency costs for parent firms operating IJVs than for their counterparts operating WoS.

Agency theory suggests that in order to reduce agency costs, parent firms may use controls over the decision-making process in a subsidiary (Johnson et al., 2001). Eisenhardt (1989: 63), for instance, maintained that agency theory is about "the optimal structuring of control relationships" to manage complexity, which arises from the difficulties in verifying the claims from subsidiary agents. This is likely to be of even bigger importance in countries, where the local partner's operational competency is questionable. Due to the relatively short opening to the global market and a communist government, it is expected to experience this in China to a great extent. Consequently, the extent of control parent firms exert over the foreign subsidiary is a means of reducing the complexity and ambiguity inherent in contractual relationships as well as aligning subsidiary managers' behavior with parent firm's corporate objectives (O'Donnell, 2000). When agency conflicts are significant, a greater extent of control may increase the efficiency of HQ-subsidiary relationships. Specifically, greater extents of control may serve as an effective means of curbing managerial opportunism and limiting the potential for irrational decision-making on the subsidiary level (Johnson et al., 2001). Moreover, higher control is expected to improve the transfer and implementation of management practices in complex relationships. In this context, parent firms seek to limit self-serving behavior of managers by exerting higher extents of control over decisions in the subsidiary, such as adjustment to local requirements as well as over the subsidiary's value chain.

Given our argumentation that the agency problem is more significant in IJVs than in WoS, we expect that parent firms increase their extent of control more strongly over IJVs than WoS, suggesting that there may not be one-to-one correspondence between ownership mode choice and the extent of control exerted over foreign subsidiaries. Johnson et al. (2001: 37) argue that "agency theory suggests that parents intervene in IJV decision-making and operations to ensure that the IJV (i.e., the agent) is serving the 
principal's (the parent firm's) agenda." Moreover, Yan and Gray (2001b) argue that the use of control may reduce the level of agency costs in IJVs resulting from the potential managerial opportunism. Building on these arguments we suggest:

Hypothesis 1 The extent of control used by a parent firm in its foreign subsidiary is higher in IJVs than in WoS.

\section{The moderating effect of cultural distance}

In the previous section, we argued that the nature and the extent of agency problems in WoS and IJVs are different, and these ownership modes may be associated with different degrees of the parent's controls used as a solution of actual or potential agency conflicts. However, we did not consider where the HQ is located and thus how the distance between the home country and the PRC is reflected in this regard. This is also a matter of uncertainty. In general, higher uncertainty urges to call for higher control (Williamson, 1991). Previous research often at least implicitly equalizes ownership and control without accounting for the specific setting the HQ-subsidiary relationship is embedded in. This shortcoming of a lack of differentiation, ignoring business realities, has already been brought to attention in the mid-1990s by Ghoshal and Moran (1996). In this section, we now extend our arguments and suggest that cultural distance further aggravates agency problems by enhancing information asymmetries between the parent firm and the subsidiary (Roth \& O'Donnell, 1996). Specifically, cultural distance can be considered one of the "realities" pointed out by Ghoshal and Moran (1996) that one needs to account for. Moreover, we argue that cultural distance affects not only the overall level of uncertainty associated with FDI, but also the balance between costs of internalization and information costs. In particular, we suggest that cultural distance affects uncertainty with different implications for the type of ownership mode-given that cultural differences complicate the verification of claims of stakeholders. Previous studies indicate that the distribution of external and internal uncertainties is different in the respective ownership modes when confronted with cultural distance (Slangen \& van Tulder, 2009). With regard to agency theory, uncertainty arises, when a principal (here the HQ) cannot accurately assess the agent's (here the subsidiary) performance (Anderson \& Gatignon, 1986). This uncertainty can for instance occur, when a company lacks experience or knowledge in certain foreign markets (Zhao, Luo, \& Suh, 2004). This often goes along with or is rooted in cultural distance, which can lead to certain forms of remedies in agency costs. Thus, it is reasonable to assume that cultural distance plays a major role in our relationship proposed in Hypothesis 1 .

With regard to the realities of doing business, we argue that cultural distance may have a differential effect on uncertainties in WoS and IJVs, since these two forms of ownership are quite different in nature. Prior research suggests that WoS are associated with higher environmental uncertainty stemming from cultural distance than IJVs (Anderson \& Gatignon, 1986; Brouthers \& Brouthers, 2001; Gatignon \& Anderson, 1988; Root, 1987; Slangen \& van Tulder, 2009). With high cultural distance, WoS are embedded in an environment that substantially differs in terms of social norms and values from the home country of the parent firm. Dealing with day-to-day operations, such as managing employees in a foreign environment or cultivating relationships with 
local stakeholders can pose problems. These different norms and values entail differences in behaviors, attitudes, cognition, and interpretation and they may complicate social interactions with local stakeholders in the host country (e.g., local buyers, suppliers, government bodies, etc.). Specifically, with growing cultural distance, parent firms lack "social knowledge" to interpret behavior of local stakeholders and thus may face considerable obstacles in predicting their social patterns (Sohn, 1994). Scholars emphasize that this understanding of the host culture cannot be acquired in advance because of its tacit nature (Yamin \& Golesorkhi, 2010). Therefore, we suggest that the parent firm's lack of social knowledge in culturally distant locations makes it difficult to verify claims from stakeholders, increasing the level of uncertainty associated with WoS. Please note that while IJVs are embedded in this environment as well, in contrast to WoS, they do have a local partner who is more familiar with the situation abroad, which is why the effects caused by cultural distance are different here. Yet, as we show later, other problems regarding cultural distance will arise here.

On the other hand, WoS are considerably less affected by an increase in cultural distance as this type of uncertainty may be mitigated by managerial hierarchy. Prior research contends that uncertainty stemming from goal incongruence and managerial conflicts is lower in WoS due to the fact that only a single owner exists (Chang \& Taylor, 1999; Geringer \& Hebert, 1989; Hedlund, 1981; Luo, Shenkar, \& Nyaw, 2001). Hence, this owner as the only principal can exercise the amount of control necessary, in order to get its agent in line. Yet, cultural distance is harder to overcome, in particular with regard to the unwritten, deeply rooted norms and believes, which cannot be ruled out just by applying hierarchy. On top of that, working with a (foreign) partner always bears the potential risk of opportunistic behavior. Based on different cultural understandings and a perceived distance to the partner, such behavior might more likely occur than when the partners are from a similar cultural context. In sum, we argue that the overall impact of the increasing cultural distance on uncertainty in WoS would be mainly associated with uncertainty arising from cultural distance.

In order to reduce the higher levels of uncertainty resulting from cultural distance in WoS past research suggests that parent firms need to leave decision-making to their foreign subsidiaries (Garnier, 1982). The higher the cultural distance, the more flexibly and rapidly the WoS needs to respond to this unfamiliar environment to adjust to cultural peculiarities and verify claims from local stakeholders in the host country. From the agency theory perspective, parent firms are thus expected to reduce the extent of control over WoS given that it may be easier to evaluate outcomes than control activities in the value chain in an environment of external uncertainty. Lee et al. (2008: 1118) argued, for instance, that parent firms relinquish control "as a way to alleviate problems in culturally distant locations", which echoes some previous studies (Agarwal, 1994; Kogut \& Singh, 1988; Shenkar, 2001). Moreover, Hedlund (1981) assumed that parent firms reduce the extent of control in order to mitigate uncertainty and information requirements resulting from cultural distance. Therefore, parent firms can reduce the level of uncertainty in culturally distant operations by reducing the extent of control over their WoS.

In contrast to WoS, IJVs are able to mitigate an increase in uncertainty resulting from cultural distance (Agarwal, 1994; Gatignon \& Anderson, 1988; Kogut \& Singh, 1988). The reason is that the local partner in an IJV can provide tacit knowledge about the host country's social norms and values and, in particular, about the behavior 
patterns of local stakeholders (Slangen \& van Tulder, 2009). The effect of cultural distance here has a different relational mechanism than argued for WoS. The local IJV partner can assist the parent firm in dealing with culturally distant stakeholders, which may alleviate information requirements and facilitate the verification of claims in the stakeholder network (Agarwal, 1994; Barkema \& Vermeulen, 1997; Gatignon \& Anderson, 1988). Therefore, we argue that the social knowledge (Sohn, 1994) contributed by the IJV partner reduces information requirements and mitigates the level of uncertainty. Lu and Hébert (2005: 738) suggested that "forming an IJV permits foreign investors to access complementary assets and to reduce accordingly the uncertainty they are confronting." Similarly, Gatignon and Anderson (1988: 307) regarded IJVs as a means of "bridging cultural gaps." Thus, past research suggests that IJVs are vehicles that provide access to tacit knowledge about the host culture and the behavior patterns of local stakeholders, reducing the level of uncertainty.

Given different contractual relations, however, IJVs are associated with higher levels of uncertainty when cultural distance increases. Following prior research (Barkema \& Vermeulen, 1997; Hennart \& Zeng, 2002), we argue that cultural distance is a key determinant of uncertainty in IJVs since these hybrid modes are - in contrast to WoS jointly managed by firms from dissimilar cultures (Luo et al., 2001). Specifically, the integration of these dissimilar cultures may involve combining different value systems, management styles, and organizational structures (Hennart \& Zeng, 2002; Kogut \& Singh, 1988), all of which may lead to divergent goals and potential conflicts in the course of IJV operations. Thus, other agency problems are arising. Slangen and van Tulder (2009) stressed that cultural differences between IJV partners may nurture goal incongruence and managerial conflicts. Dealing with the local IJV partner can be quite difficult, a phenomenon that does not arise in WoS. Yan and Gray (2001b: 304) maintained that "the agency problem in IJVs is rooted in the divergent self-interests of the parents and their objectives for the venture's operation", which is especially the case when cultural distance is high. Therefore, with growing cultural distance, IJVs are exposed to higher levels of uncertainty as cultural distance may increase the likelihood of goal incongruence and managerial conflicts, and subsequently complicate the verification of claims in IJV operations (Gatignon \& Anderson, 1988; Gaur \& Lu, 2007; Meschi \& Riccio, 2008).

Previous research suggests that, to manage an increase in uncertainty in IJVs, parent firms need to increase the extent of control in foreign subsidiaries (Chang \& Taylor, 1999; Geringer \& Hebert, 1989; Hedlund, 1981; Luo et al., 2001). Control is considered as a means of reducing the likelihood of goal incongruence and managerial conflicts, which ultimately facilitates the verification of claims in the course of IJV operations. Johnson et al. (2001: 38) contended that the cultural distance between joint venture partners influences "the entire joint venture dynamic" entailing consequences for parent firm's extent of control over the venture. Moreover, Luo et al. (2001) argued that parent firms should seek control in case of high cultural distance and goal incongruence. Geringer and Hebert (1989: 244) argued that "control is a mechanism for reducing the risks associated with coordination, potential conflicts and (...) consequently, for minimizing transaction costs." Moreover, Chang and Taylor (1999) reported that high uncertainty increases the MNC's reliance on control given that control curbs the potential of undesirable behavior and actions. Finally, Hedlund (1981) suggested that parent firms enhance the extent of control over their foreign subsidiaries to mitigate 
high levels of uncertainty stemming from cultural distance and ultimately increase efficiency. Taken together, parent firms can reduce the level of uncertainty in IJVs by enhancing their extent of control.

Overall, based on agency theory, these arguments suggest that, due to different levels of uncertainty, cultural distance moderates the relationship between the type of ownership mode and the extent of control. Yet, with regard to the different realities (Ghoshal \& Moran, 1996) arising due to the ownership mode, the direction of cultural distance as a moderator differs. Specifically, since, compared to IJVs, WoS are associated with higher uncertainty regarding operations in the host culture, with increasing cultural distance parent firms are expected to increase the extent of control more strongly in IJVs than in WoS. Hence, we suggest the following hypothesis:

Hypothesis 2 The relationship between the ownership mode and the extent of control is moderated by the level of cultural distance. The higher the cultural distance, the lower the extent of the parent firm's control over WoS and the higher the extent of control over IJVs.

\section{Research design and methodology}

\section{Data origin and sample}

To test our theoretical propositions, in March and April 2010 we collected primary data from foreign firms located in the PRC through a questionnaire survey. Parent firms were headquartered in Europe, Japan, and the United States. We deliberately excluded investors from Hong Kong, Macao, Malaysia, Singapore, and Taiwan as well as offshore financial hubs (e.g., Virgin Islands or Western Samoa) to reduce possibilities of round-tripping investments (Xiao, 2004) and investments from overseas Chinese firms since these financial investments cannot be compared with investments from other investors. To compile a comprehensive dataset of contact addresses we contacted national chambers of foreign trade of Germany, Japan, the UK, the US, and additional countries within the European Union. Moreover, we analyzed corporate web pages and articles in newspapers such as China Business Review to collect additional contact information. Overall, we identified contact details of 1,979 IJVs and WoS of foreign firms in the PRC. Professional translators translated the original German language questionnaire into English, French, Spanish, and Japanese using the translate/backtranslate method to ensure the equivalency of the questionnaires (Brislin, 1970). The questionnaire was distributed online together with an executive summary that detailed the objective of the study. Those firms that had not replied by the originally set deadline received a reminder two weeks later. After a second deadline, we collected 195 questionnaires which corresponds to a response rate of $9.90 \%$. Due to missing information, unclear ownership of the subsidiary, or recent ownership changes towards a financial investor from an offshore location, data analysis was based on 156 cases. In our sample, subsidiaries were established by firms headquartered in 13 countries, with Germany, Japan, the UK, and the US accounting for the majority of investments. Moreover, $82 \%$ of the respondents were general managers of the respective subsidiary, $7 \%$ were subsidiary CFOs, and $6 \%$ were marketing managers. 
We assessed non-response bias by using an approach developed by Armstrong and Overton (1977). A comparison of early- and late-arriving responses by means of logistic regression indicated that the likelihood of a non-response bias for our study variables was low. Therefore, non-response bias was unlikely to represent a problem in our study. Since our dependent variable was constructed using primary data, our independent variable is a dichotomous yes/no variable, and our moderator is derived from secondary sources, common method bias can only exist at the level of control variables. Still, to minimize common method bias, we followed the methodological approach suggested by Podsakoff, MacKenzie, Jeong-Yeon, and Podsakoff (2003). We thus separated items measuring the same construct in the questionnaire, protected the anonymity of respondents, and mitigated the danger of evaluation apprehension by explaining in the executive summary that there were neither "right" nor "wrong" answers.

\section{Operationalization of variables}

\section{Dependent variable}

Following Geringer and Hebert (1989) we measured the "extent of control" over a specific "scope" of activities. We used the extent of autonomy from HQ as our starting point and defined it as inverted measure of centralization of decision-making that takes place at the parent firm. In particular, we asked managers to assess the extent of autonomy from HQ on the following six dimensions, each assessed by means of a seven-point Likert scale item: strategic decisions, research and development, organization of production, organization of distribution, budget responsibility and adjustment to local requirements. Inverting this measure allowed us to assess, how much actual control the respective WoS or IJV in China perceives from HQ. We averaged these items to form our measure of control with higher scores indicating higher control. The construct showed good internal consistency $(\alpha=.79)$. To examine the construct validity and discriminant validity of this measure, we conducted a confirmatory factor analysis as suggested by an anonymous reviewer. Specifically, we examined all multiitem measures used in this study, which includes our dependent variable of control and also two control variables, knowledge development and resource sharing (for a description see section on control variables). Only a three factor model fit the data well $\left(\chi^{2}(101)=186,09 ; \mathrm{RMSEA}=.07 ; \mathrm{CFI}=.93 ; \mathrm{SRMR}=.08\right)$ whereas a single factor model or all other possible models with two factors (i.e., items of two scales load on a single factor and items of the third scale on an additional factor) did not provide adequate fit (for these models: RMSEA > .12; CFI < .80; SRMR > .12). In addition, the three factor model fit significantly better than any of these models. This analysis suggests that our dependent measure forms a single construct that is distinct from the other scales we use.

\section{Independent variable}

The ownership mode of the subsidiary was measured using a dichotomous variable, assigned 0 if the subsidiary operated as an IJV and 1 if the subsidiary was a WoS (Brouthers, Brouthers, \& Werner, 2003; Hennart \& Larimo, 1998; Padmanabhan \& 
Cho, 1996). IJVs were defined according to Chinese regulations that use the $30 / 70 \%$ cut-off point to classify IJVs and distinguish them from WoS. This is in line with previous studies (for similar conceptualizations, see Brouthers et al., 2003; Hennart \& Larimo, 1998; Padmanabhan \& Cho, 1996). An additional benefit of opting for an operationalization following regulations of the Chinese government is that it avoids confusion among the respondents of "what" an IJV is and what is not. They have a very clear understanding that is based exactly on these regulations. In our sample, we only included sino-foreign ventures, but no foreign-foreign or sino-sino ventures.

\section{Moderating variable}

We measured the cultural distance between home countries of parent firms and the PRC using Hofstede's $(1980,2001)$ metrics and the index developed by Kogut and Singh (1988). Specifically, we calculated a composite index of cultural distance for each country pair using the following formula:

$$
C D_{j k}=\frac{\left(D_{i j}-D_{i k}\right)^{2}}{V_{i}} / 4
$$

$\mathrm{CD}_{\mathrm{jk}}$ reflects the cultural distance between country $j$ and China $(k), \mathrm{D}_{\mathrm{ij}}$ reflects the value of country $j$ and $\mathrm{D}_{\mathrm{ik}}$ the value of China on the cultural dimension $i$, and $\mathrm{V}_{\mathrm{i}}$ stands for the variance of the cultural dimension index $i$.

Hofstede's $(1980,2001)$ study has also been subject to criticism. For instance, some scholars indicated that his four dimensions of culture are not exhaustive because his study was not initially geared towards identifying dimensions along which countries differ (Javidan, House, Dorfman, Hanges, \& de Luque, 2006). Despite these concerns, Hofstede's $(1980,2001)$ metrics continue to be widely applied in IB research as the relevance of his dimensions has been empirically validated in numerous studies (Magnusson, Wilson, Zdravkovic, Joyce Xin, \& Westjohn, 2008). For instance, Kim and Gray (2009) provided empirical evidence that Hofstede's metrics outperformed GLOBE in explaining governance choices in Korea. Furthermore, Drogendijk and Slangen (2006) found that Hofstede's measures of culture outperformed the explanatory power of managerial perceptions in explaining establishment mode choices by parent firms. They concluded that "it may thus be premature to dismiss Hofstede's work as outdated or as inaccurately" (Drogendijk \& Slangen, 2006: 362).

In our study, we thus relied on Hofstede's $(1980,2001)$ data as scholars have repeatedly pointed to the validity and reliability of his metrics (Brouthers \& Brouthers, 2001; Chan \& Makino, 2007; Morosini, Shane, \& Singh, 1998). Consequently, we believe that Hofstede's metrics still capture important cultural differences as evidenced by the large number of empirical studies that have used his data in IB research (Barkema, Bell, \& Pennings, 1996; Barkema \& Vermeulen, 1997; Benito \& Gripsrud, 1992; Chan \& Makino, 2007; Cho \& Padmanabhan, 2005; Dow \& Ferencikova, 2010; Morosini et al., 1998; Yiu \& Makino, 2002). However, as reported below, we conducted tests with other measures of cultural distance as robustness checks (see analyses section), all pointing in the same direction.

Furthermore, we use the formula of Kogut and Singh (1988) for the purpose of our study to calculate cultural distances between home countries of parent firms and China. This formula bears the advantage that it accounts for differences in the variance of 
dimensions and does not merely form averages. Additionally, scholars maintain that employing the Kogut and Singh (1988) index mitigates problems associated with common method bias and retrospective evaluation (Morosini et al., 1998). Moreover, we refrained from using the Euclidean approach since we have no theoretical reason to assume that some dimensions of cultural distance are more important than others (Vermeulen \& Barkema, 2001). Overall, we believe that the Kogut and Singh (1988) index adequately captures distances between countries as evidenced by numerous previous studies that had relied on this calculation method in combination with Hofstede's metrics in IB research (Barkema et al., 1996; Barkema \& Vermeulen, 1997; Benito \& Gripsrud, 1992; Chan \& Makino, 2007; Cho \& Padmanabhan, 2005; Dow \& Ferencikova, 2010; Morosini et al., 1998; Yiu \& Makino, 2002).

\section{Control variables}

Based on the literature and substantive considerations, we originally selected 13 variables that might affect ownership form and control to rule out alternative explanations for our findings. Following Becker's (2005) recommendations, we decided to exclude impotent control variables, that is, those variables that do not explain variance in our regression equations and thus reduce power. To minimize type II errors, we used a very conservative criterion, including all control variables that were "significant" at $p$ $<.20$. This resulted in the inclusion of eight control variables in our substantive analyses.

First, we included a measure of competitive pressure, given that a highly competitive environment influences the level of external uncertainty and information costs, prompting parent firms to reduce the extent of control over their foreign subsidiaries (Gates \& Egelhoff, 1986; Hedlund, 1981). To measure competitive pressure, we used a four-item measure used by Kim and Hwang (1992). We asked managers to evaluate the degree of instability of the market share, the number of existing and potential competitors, the level of fixed costs relative to the added value, and the costs associated with switching suppliers. Answers to these questions were measured on seven-point Likerttype scales and averaged to form a scale of competitive pressure for the present analyses $(\alpha=.89)$.

In addition, following previous research (Birkinshaw et al., 1998; Edwards, Ahmad, \& Moss, 2002) we used knowledge development as a control variable. Respondents were asked to rate China-specific knowledge available in their subsidiary at market entry on the following five dimensions: market knowledge, knowledge about the regulatory framework, the economic conditions, the political situation, and the Chinese business culture. Answers to these questions were measured on seven-point Likert-type scales ranging from 1 (the level of knowledge is/was much lower than at the time we entered the market) to 7 (the level of local knowledge is/was much higher than at the time we entered this market). The internal consistency of the construct proved to be high $(\alpha=.85)$.

We also control for industry sectors on the basis of SIC codes, as previous studies have suggested that parental control differs by industry (Makhija, Kim, \& Williamson, 1997) and opportunities to form a WoS or IJV might differ across industry sectors. We used the 10 category division coding system as our sample included a host of sparsely populated two-digit major industry codes. The companies came from 7 out of 10 divisions, that is, our sample did not contain companies from public mining (Division 
B), construction (Division C), and public administration (Division J). In our regression analyses, we used six dummy variables to contrast manufacturing (Division D) with other divisions.

We included several single item measures assessing characteristics of the subsidiary. These were the age of the subsidiary since previous studies have suggested that with increasing age parent firms reduce the extent of control over foreign subsidiaries (Chang \& Taylor, 1999; Garnier, 1982; Gates \& Egelhoff, 1986; Harzing, 1999; Taggart \& Hood, 1999; Van den Bulcke \& Halsberghe, 1984). We used the length of time in years that had passed since the foundation of the subsidiary in the PRC as a measure for subsidiary age (Hennart, 1991). We also included the type of subsidiary as a control variable given that prior research suggested that the competencies of the subsidiary level influence parental control (Taggart \& Hood, 1999; Young, Hood, \& Hamill, 1985). We measured type of subsidiary using a dichotomous variable, assigned 0 if the subsidiary is involved in full operations and 1 if the subsidiary only performs sales and service activities. Moreover, we included the number of employees of the subsidiary to control for potential effects of subsidiary size, which refers to a subsidiary's resource position and possibly higher discretion in decision-making.

Finally, we also included two control variables reflecting parent firm characteristics as they might affect control of subsidiaries. Specifically, we included the number of countries in which a parent firm operated subsidiaries as a measure of experience and also the parent firm's number of employees worldwide to reflect its resource position.

We also checked the potency of the five following control variables, but did not include them in our analyses, as they did not explain a substantial amount of variance in our dependent measure (at a conservative $p<.20$ ). Note, that including these variables did not change substantive findings, that is, they were in fact "impotent" in the present analysis (Becker, 2005). The first was a five-item measure of resource sharing taken from Davis, Desai, and Francis (2000) $(\alpha=$ .74) as research has suggested that high levels of resource sharing between the parent firm and the foreign subsidiary leads to higher extents of control (Andersson \& Forsgren, 1996; Birkinshaw \& Morrison, 1995). Second, we assessed the level of asset specificity using items developed by Brouthers and Brouthers (2003) $(\alpha=$.78). Asset specificity is assumed to increase internal uncertainty since it induces partners to behave opportunistically and exploit unilateral dependencies. In order to curb opportunism and protect firm-specific assets scholars have suggested that parent firms enhance the extent of control over their foreign subsidiaries (Geringer \& Hebert, 1989; Mjoen \& Tallman, 1997; Yan \& Gray, 2001a). Third, we used a dichotomous measure whether the product/ service provided is the same vs. different from the parent firm, to assess diversification (see also Chang \& Rosenzweig, 2001; Kogut \& Singh, 1988). Diversification refers to the responsiveness to local market needs and may prompt parent firms to reduce control (Martinez \& Jarillo, 1991; Roth \& Morrison, 1992). In addition, the number of subsidiaries in the PRC as a measure of China-specific experience (e.g., Harzing, 1999; Taggart \& Hood, 1999) and the total amount of investment in the subsidiary as an additional measure of the subsidiary's resource position (next to the number of employees that was included). 


\section{Analyses}

We employed hierarchical multiple regression (Aguinis, 1995) to test our theoretical propositions using control variables as stated in the previous section. To simplify the interpretation of interaction effects, we standardized cultural distance prior to the analyses.

As we use observational data, our independent variable ownership form does not reflect random treatment assignment and is thus subject to endogeneity concerns. WoS and IJV might not be fully comparable, because the decision for either option might have been affected by differences between parent firms, the situation or other variables. As it is hardly possible to identify and include all potential variables in our analyses, omitted variables might affect ownership form as well as control and thus our regression analyses might yield biased results (note however, that including control variables in regression analyses is one possible means to tackle endogeneity bias, e.g., Reeb, Sakakibara, \& Mahmood, 2012).

To alleviate endogeneity problems, we also ran additional analyses using propensity score matching (Rosenbaum \& Rubin, 1983; for a review see Stuart, 2010). This method has been applied in several other studies in international business research (e.g., Cassiman \& Golovko, 2011; Chang, Chung, \& Moon, 2013) and has been recommended in a prominent IB Journal (Reeb et al., 2012). In essence, the method attempts to create a situation that comes as close to randomized experiments as possible in three steps. First, observed variables are used to estimate a propensity score that indicates the probability of receiving treatment, or, in the present case, of creating a WoS or IJV. This propensity score includes all available information from control variables on differences between groups. In a second step, the propensity score is used to match similar observations resulting in groups that are comparable with regard to their propensity to belong to the groups of WoS and IJV, respectively. In a final step, differences between matched groups on the dependent variable are compared using appropriate statistical tests, typically without control variables (e.g., a $t$-test). In contrast to regression analyses that adjust for effects of control variables on the outcome (i.e., our dependent measure of control), propensity score analysis adjusts for effects of variables on the independent variable (i.e., ownership form; Schafer \& Kang, 2008). It therefore complements our regression analysis and provides additional evidence, albeit no proof, against endogeneity concerns.

In the present analysis we used logistic regression including all 13 control variables to estimate propensity scores, as over-fitting is typically recommended (e.g., Schafer \& Kang, 2008). Although our sample appears to be small in comparison to large scale surveys that have employed this method, others have shown that matching reduces bias substantially even in small samples (e.g., Gu \& Rosenbaum, 1992 use 50 units in each, treatment and control group, see also Rubin, 1979). We employed 1:1 matching using the nearest neighbor method, which is the most often used matching procedure (Thoemmes \& Kim, 2011). We used a caliper of .25 as suggested by Rosenbaum and Rubin (1983) to prevent matching of highly dissimilar observations. Note that in comparison to other matching methods (e.g., full matching, nearest neighbor matching using different calipers, 1:many ratio matching), this method provided the best balance between the two matched groups as estimated by standardized mean difference between 
groups on control variables (Stuart, 2010). To examine our hypotheses, we used a regression analysis, as Hypothesis 2 refers to an interaction effect of ownership form and cultural distance.

\section{Results}

Table 1 shows the means, standard deviations, and bivariate Pearson correlations. In our sample, $60 \%$ of the subsidiaries were WoS and the mean age of the subsidiaries was 8.8 years $(\mathrm{SD}=6.2)$. In line with our expectations, the ownership mode variable is negatively and strongly significantly correlated with the control variable, but it is not correlated with cultural distance.

Results of hierarchical regression analyses for three models are depicted in Table 2. Model 1 contains control variables only. In Model 2, the main effects of ownership mode and cultural distance are added. The type of ownership mode has a significant

Table 1 Means, standard deviations, and bivariate Pearson correlations

\begin{tabular}{|c|c|c|c|c|c|c|c|c|c|c|c|c|}
\hline No. & Variable & Mean & SD & 1 & 2 & 3 & 4 & 5 & 6 & 7 & 8 & 9 \\
\hline 1 & $\begin{array}{r}\text { Extent of } \\
\text { control }\end{array}$ & 3.43 & 1.21 & & & & & & & & & \\
\hline 2 & $\begin{array}{l}\text { Ownership } \\
\text { mode }\end{array}$ & .60 & .49 & $-.21^{* * *}$ & & & & & & & & \\
\hline 3 & $\begin{array}{l}\text { Cultural } \\
\text { distance }\end{array}$ & 2.50 & .58 & -.11 & -.03 & & & & & & & \\
\hline 4 & $\begin{array}{c}\text { Competitive } \\
\text { pressure }\end{array}$ & 5.35 & 1.37 & .11 & -.14 & -.01 & & & & & & \\
\hline 5 & $\begin{array}{l}\text { Knowledge } \\
\text { development }\end{array}$ & 5.55 & 1.04 & $-.25^{* *}$ & -.04 & .11 & .15 & & & & & \\
\hline 6 & $\begin{array}{l}\text { Age of } \\
\text { subsidiary }\end{array}$ & 8.77 & 6.17 & .13 & -.08 & -.01 & .15 & $.22^{* * *}$ & & & & \\
\hline 7 & $\begin{array}{l}\text { Type of } \\
\text { subsidiary }\end{array}$ & .85 & .36 & -.10 & $-.17^{*}$ & .04 & .05 & .15 & -.01 & & & \\
\hline 8 & $\begin{array}{l}\text { Number of } \\
\text { employees in } \\
\text { subsidiary }\end{array}$ & 756.67 & 2201.36 & .05 & .01 & -.01 & -.05 & .09 & .11 & -.07 & & \\
\hline 9 & $\begin{array}{l}\text { Parent firm: } \\
\text { Number of } \\
\text { countries } \\
\text { with } \\
\text { subsidiares }\end{array}$ & 2.53 & .76 & .10 & -.15 & -.01 & .10 & $.20^{*}$ & $.28^{* *}$ & .13 & .15 & \\
\hline 10 & $\begin{array}{l}\text { Parent firm: } \\
\text { Number of } \\
\text { employees } \\
\text { worldwide } \\
\text { (in thousand) }\end{array}$ & 63.60 & 126.21 & -.03 & $-.29^{* * *}$ & -.15 & .10 & .01 & $.26^{* * *}$ & -.06 & $.29^{* * *}$ & $.30^{\text {*** }}$ \\
\hline
\end{tabular}

$N=156$. Ownership mode $(0=\mathrm{IJV} ; 1=\mathrm{WoS})$ and Type of subsidiary $(0=$ sales $\&$ service $; 1=$ full operation are dichotomous variables. Dummy variables for SIC divisions are not shown

${ }^{*} p<.05 ;{ }^{* *} p<.01$ 
Table 2 Results of hierarchical regression analysis

\begin{tabular}{|c|c|c|c|}
\hline & Model 1 & Model 2 & Model 3 \\
\hline \multicolumn{4}{|l|}{ Control effects } \\
\hline \multicolumn{4}{|l|}{ SIC code } \\
\hline Division A (Agriculture) & -.61 & -.69 & -.72 \\
\hline Division E (Transportation) & -.45 & -.59 & -.57 \\
\hline Division F (Wholesale trade) & -.04 & -.34 & -.24 \\
\hline Division G (Retail trade) & .22 & -.14 & -.30 \\
\hline Division H (Finance) & -1.04 & -.91 & -.69 \\
\hline Division I (Services) & $-.67^{\dagger}$ & -.53 & -.48 \\
\hline Competitive pressure & $.14^{\dagger}$ & .11 & $.12^{\dagger}$ \\
\hline Knowledge development & $-.39^{* *}$ & $-.37^{* *}$ & $-.38^{* *}$ \\
\hline Age of subsidiary & $.03^{\dagger}$ & $.04^{*}$ & $.04^{*}$ \\
\hline Type of subsidiary & -.49 & $-.64^{*}$ & $-.59^{\dagger}$ \\
\hline Number of employees in subsidiary & .00 & .00 & $.00^{\dagger}$ \\
\hline Parent firm: Number of countries with subsidiares & .20 & .20 & .16 \\
\hline Parent firm: Number of employees worldwide (in thousand) & $-.01^{*}$ & $-.01^{* *}$ & $-.01^{* *}$ \\
\hline \multicolumn{4}{|l|}{ Direct effects } \\
\hline Ownership mode & & $-.64^{* *}$ & $-.64^{* *}$ \\
\hline Cultural distance & & -.13 & .11 \\
\hline \multicolumn{4}{|l|}{ Moderating effects } \\
\hline Ownership mode $\times$ Cultural distance & & & $-.46^{*}$ \\
\hline Constant term & 4.67 & 5.24 & 5.26 \\
\hline Total $R^{2}$ & $.19^{* *}$ & $.25^{* *}$ & $.29^{* *}$ \\
\hline$\Delta R^{2}$ & & $.06^{* *}$ & $.03^{*}$ \\
\hline
\end{tabular}

$N=156$. Ownership mode $(0=\mathrm{IJV} ; 1=\mathrm{WoS})$ and Type of subsidiary $(0=$ sales $\&$ service; $1=$ full operation $)$. SIC Division D (Manufacturing) was used as reference category. Cultural distance was standardized for this analysis

${ }^{\dagger} p<.10 ;{ }^{*} p<.05 ;{ }^{* *} p<.01$

negative effect on the extent of control, indeed indicating that WoS experience lower levels of control than IJVs. Thus, Hypothesis 1 is supported.

In Model 3, we entered the interaction term of ownership mode and cultural distance as a test of Hypothesis 2. Entering the interaction term improved model fit significantly $\left(\Delta R^{2}=.03 ; p<.05\right)$. Moreover, the coefficient of the interaction term is significant $(\beta=$ $-.46 ; p<.05)$, supporting Hypothesis 2 . Hence, cultural distance indeed moderates the relationship between the type of ownership mode and the extent of control. In order to further examine this finding, we conducted a simple slope analysis following the procedure suggested by Aiken and West (1991) and plotted this effect. Figure 1 shows that the relationship between cultural distance and extent of control is negative for WoS and positive for IJVs. While IJVs and WoS do not differ in terms of extent of control when cultural distance is low, parent firms increase the extent of control in IJVs and reduce it in WoS with increasing cultural distance. As checks of model robustness, we tested our model using different sets of control variables (see Table 3), for example 


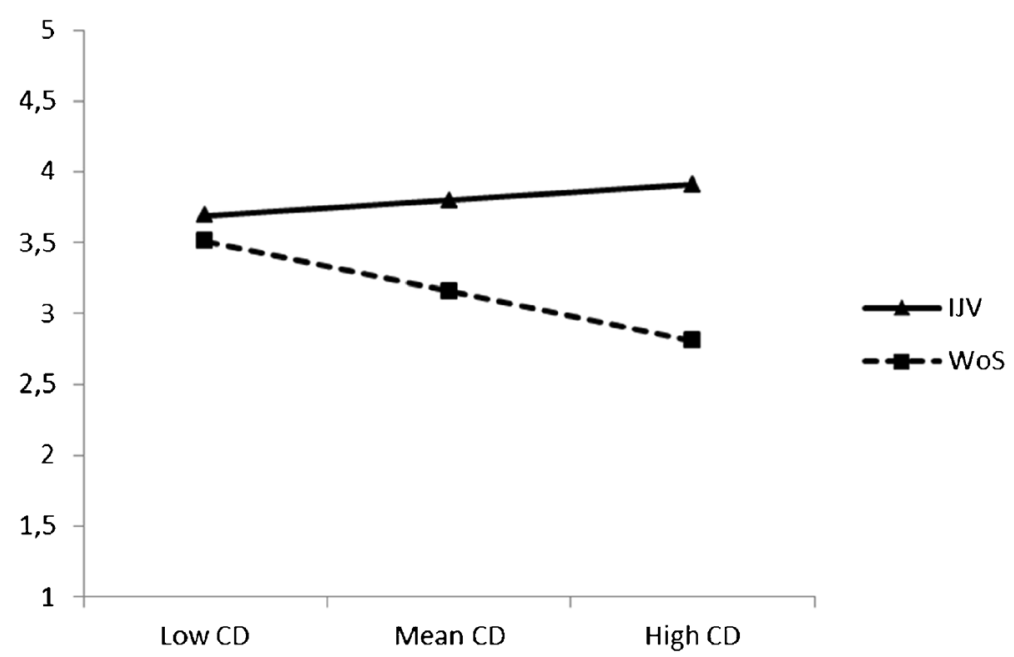

Fig. 1 Moderating effect of cultural distance on the relationship between ownership mode and extent of control

using no control variables (i.e., a test for suppressor relations, see Model 2), as well as additional controls for institutional distance as suggested by a reviewer (Model 3 in Table 3). In addition, since Kogut and Singh's (1988) composite measure of cultural distance is a relatively broad construct, a post-hoc analysis was performed, entering separate dimensions of cultural distance in a regression model. Results from Model 4 showed no significant difference for any of the dimensions, suggesting to keeping the model in its original version with cultural dimension as a composite construct. Overall, all our tests lend support for our hypothesis at hand.

In terms of control variables, knowledge development significantly reduced the extent of control over foreign subsidiaries. This result is in line with previous studies, which corroborated that highly knowledgeable subsidiaries enjoy greater levels of autonomy (Edwards et al., 2002). The age of the subsidiary had a significant positive effect on the extent of control, even though one would expect otherwise. However, some studies also support our finding (Chang \& Taylor, 1999; Hedlund, 1981; Young et al., 1985), and an explanation for this result may be that in high growth markets such as the PRC, parent firms prefer to retain a high extent of control to exploit economies of scale even after several years of operations (Agarwal \& Ramaswami, 1992; Brouthers, 2002). The type of subsidiary marginally reduced the extent of control over subsidiaries, suggesting that full operation subsidiaries are less controlled than sales and service subsidiaries. This finding is in line with the results of Young et al. (1985) who found that marketing activities are among the most centralized decision areas in subsidiaries. Size of the subsidiary entered the regressions marginally positively as expected. Larger subsidiaries are thus more intensely controlled, what may be the consequence of the relevance of their assets that is reflected in their size. Also size of the parent firm had marginally significant effects on control. Large firms control their subsidiaries less intensely than small firms, maybe because of the smaller relative size of the 
Table 3 Robustness checks

\begin{tabular}{|c|c|c|c|}
\hline & Additional comments & $\begin{array}{l}\text { Test of } \\
\text { Hypothesis } 1\end{array}$ & $\begin{array}{l}\text { Test of } \\
\text { Hypothesis } 2\end{array}$ \\
\hline 1) Model as depicted in Table 2 & Includes eight control variables & $\begin{array}{l}\Delta R^{2}=.06^{* *} \\
b=-.64^{* *}\end{array}$ & $\begin{array}{l}\Delta R^{2}=.03^{*} \\
b=-.46^{* *}\end{array}$ \\
\hline 2) Model 1 without control variables & & $\begin{array}{l}\Delta R^{2}=.06^{* *} \\
b=-.52^{* *}\end{array}$ & $\begin{array}{l}\Delta R^{2}=.04^{* *} \\
b=-.51^{* *}\end{array}$ \\
\hline $\begin{array}{l}\text { 3) Model } 1 \text { and three additional } \\
\text { variables to control for } \\
\text { institutional distance } \\
\text { (Reviewer suggestion) }\end{array}$ & $\begin{array}{l}\text { Institutional distance assessed by: } \\
\text { Political distance: POLCON } \\
\text { Economic distance: GDP/capita } \\
\text { difference } \\
\text { Geographic distance: distance } \\
\text { in } \mathrm{km}\end{array}$ & $\begin{array}{l}\Delta R^{2}=.07^{* *} \\
b=-.70^{* *}\end{array}$ & $\begin{array}{l}\Delta R^{2}=.03^{*} \\
b=-.45^{*}\end{array}$ \\
\hline $\begin{array}{l}\text { 4) Model } 1 \text { using Hofstede's } 4 \\
\text { separate distance measures } \\
\text { instead of single CD score }\end{array}$ & $\begin{array}{l}\text { Power distance (PD), uncertainty } \\
\text { avoidance (UA), individualism } \\
\text { (IND), masculinity (MAS) }\end{array}$ & $\begin{array}{l}\Delta R^{2}=.07^{* *} \\
b=-.52^{* *}\end{array}$ & $\begin{array}{l}\Delta R^{2}=.04 \\
\text { PD: } b=-.32 \\
\text { UA: } b=-.44 \\
\text { IND: } b=-.74 \\
\text { MAS: } b=-.23\end{array}$ \\
\hline $\begin{array}{l}\text { 5) Model using propensity score } \\
\text { matching, no control variables }\end{array}$ & $\begin{array}{l}N=84 \text { (42 matched pairs of } \\
\text { IJVs and WOSs); NN } \\
\text { matching with caliper }=.25\end{array}$ & $\begin{array}{l}\Delta R^{2}=.05^{*} \\
b=-.50^{*}\end{array}$ & $\begin{array}{l}\Delta R^{2}=.05^{*} \\
b=-.54^{*}\end{array}$ \\
\hline $\begin{array}{l}\text { 6) Model using propensity score } \\
\text { matching and controls from } \\
\text { Table } 2\end{array}$ & $\begin{array}{l}N=84(42 \text { matched pairs of IJVs } \\
\text { and WOSs); NN matching with } \\
\text { caliper }=.25\end{array}$ & $\begin{array}{l}\Delta R^{2}=.04^{*} \\
b=-.50^{*}\end{array}$ & $\begin{array}{l}\Delta R^{2}=.07^{*} \\
b=-.64^{*}\end{array}$ \\
\hline $\begin{array}{l}\text { 7) Model using 1: many propensity } \\
\text { score matching and controls } \\
\text { from Table } 2\end{array}$ & $\begin{array}{l}N=99(56 \mathrm{IJVs} \text { and } 43 \mathrm{WoSs}) ; \\
\mathrm{NN} \text { matching with } \\
\quad \text { caliper }=.25\end{array}$ & $\begin{array}{l}\Delta R^{2}=.06^{*} \\
b=-.62^{* *}\end{array}$ & $\begin{array}{l}\Delta R^{2}=.05^{* *} \\
b=-.58^{* *}\end{array}$ \\
\hline
\end{tabular}

All tests show results from multiple regression analyses. Hypothesis 1 tests the effect of ownership form on control. Hypothesis 2 tests the moderating effect of cultural distance

${ }^{*} p<.05 ;{ }^{* *} p<.01$

subsidiary in comparison to the fully array of activities of the MNC. Finally, we found no significant effects of industry sectors based on SIC codes on control.

To further examine our hypotheses and to empirically address potential endogeneity in our models, we additionally performed analyses based on propensity score matching. As we used a caliper to prevent matching of dissimilar firms, we obtained 42 matches, that is, the sample size for this analysis is $N=84$. As shown in Table 4, matching was successful as indicated by small mean differences in matching variables after matching (i.e., $d<.25$ for all variables, see Stuart, 2010). In support of Hypothesis 1, our analyses indicated that ownership form exerted a significant effect on control $(b=-.50 ; p<.05)$ in the matched sample (see robustness checks in Table 3). Hypothesis 2 also received support as the interaction of ownership form and cultural distance significantly improved model fit $\left(\Delta R^{2}=.05 ; p<.05\right)$ and the effect of the moderator was significant $(b$ $=-.54 ; p<.05)$. Moreover, substantive findings were robust when varying specifications of our analyses (see Table 3) and also held when using the original control variables in regression analyses (i.e., a double robust analysis, see Stuart, 2010). 
Table 4 Standardized mean differences before and after propensity score matching

\begin{tabular}{lcc}
\hline Variable & $d$ before matching & $d$ after matching \\
\hline Competitive pressure & -.29 & .15 \\
Resource dependency & .37 & -.05 \\
Asset specifity & -.31 & -.01 \\
Knowledge development & -.08 & .16 \\
Age of subsidiary & -.16 & .14 \\
Type of subsidiary & -.33 & .09 \\
Product/service similarity to parent firm & -.33 & -.12 \\
Parent firm: Number of subsidiaries in PRC & -.38 & .01 \\
Parent firm: Number of countries with subsidiaries & -.32 & .13 \\
Number of employees in subsidiary & .02 & .20 \\
Parent firm: Number of employees worldwide (in thousand) & -.61 & .19 \\
Parent firm: Total investment in subsidiary & -.30 & .18 \\
\hline
\end{tabular}

$N=156$ before matching (63 IJVs and $93 \mathrm{WoSs}$ ). $N=84$ after matching with 42 IJVs and 42 WoSs

\section{Discussion}

Our research has a number of important implications for IB studies grounded within the agency framework. Previous research has focused on the governance characteristics of a parent firm's ownership stake in an overseas subsidiary, often equating it with the extent of control a parent may have over a subsidiary's decision-making process. In this study, we argue that the ownership mode has a negative effect on the extent of control, that is, the extent of decision-making that actually takes place at the parent firm, exerted over foreign subsidiaries with parent firms having higher extent of control over IJVs than over WoS. We theorize that IJVs and WoS represent not only different contractual arrangements but, more importantly, also different types of agency conflicts. While IJVs are contracts characterized by multiple parties involved, WoS represent contracts with a traditional principal-agent relationship. Specifically, we argue that the complexity of the contractual relationship and ambiguity of subsidiary managers' actions and behavior associated with the joint management of foreign operations jointly lead to higher agency costs for parent firms operating IJVs compared to their counterparts operating WoS. To reduce agency costs, a parent firm may seek higher control over its subsidiary's decisions. Since agency problems are more significant in IJVs than in WoS, parent firms increase their extent of control more strongly over IJVs than WoS, suggesting that the type of ownership mode can significantly differ from the extent of control exerted over foreign subsidiaries. In fact, it does not only differ, it also determines. Therefore, it is necessary to clearly distinguish between ownership rights and the actual extent of control over foreign subsidiaries as "equity position and control are two conceptually different constructs" (Mjoen \& Tallman, 1997: 261).

We further extend these arguments by suggesting that agency conflicts in foreign subsidiaries are far from being universal, and they may be contingent on differences in institutional environments between home and host countries. More specifically, we show that the relationship between the ownership mode and the extent of control 
exerted over foreign subsidiaries severely depends on the contextual environment, in particular the cultural distance between home and host country. Our analysis clearly indicates that the level of cultural distance moderates the relationship between ownership mode and the extent of control: the higher the cultural distance, the lower the extent of control over WoS and the higher the extent of control over IJVs. Our arguments are based on the assumption that cultural distance affects both external and internal uncertainties associated with foreign subsidiaries. We suggest that the distribution of external and internal uncertainties in IJVs and WoS differ when confronted with cultural distance due to the different contractual relations underlying these ownership modes. While IJVs are characterized by higher levels of internal uncertainty, WoS are characterized by lower levels of internal uncertainty. Following prior research, we argue that parent firms respond to this increased internal uncertainty by enhancing the extent of strategic control in IJVs. On the other hand, external uncertainty associated with WoS is higher than with IJVs. In order to mitigate this external uncertainty associated with high cultural distance, parent firms reduce the extent of strategic control and leave decision-making to the WoS. Therefore, cultural distance moderates the relationship between ownership mode and control, with the interplay of external and internal uncertainty levels determining the extent of strategic control parent firms exert over their foreign subsidiaries. This is a novel and important finding with strong implications for future research.

Our study contributes to research on subsidiary initiatives by suggesting that the extent of control parent firms exert over their subsidiaries does not only depend on their generation and contribution of firm-specific assets (Birkinshaw et al., 1998) or the type of mandate they develop within the global MNC network (Birkinshaw \& Morrison, 1995), but also on the ownership mode. Moreover, our findings clearly indicate that the respective mandate of a subsidiary depends not only on ownership mode alone, but also depends on the extent. The cultural distance between the home country of the parent firm and its subsidiary's location proved to be an important and significant moderator of the aforementioned relationship. Therefore, research on subsidiary initiatives needs to acknowledge that cultural distance affects both the external and internal uncertainty associated with foreign subsidiaries since it complicates the verification of claims of both external and internal agents.

We also make a contribution to IB studies that apply agency theory to describe HQsubsidiary relations (Chang \& Taylor, 1999; O'Donnell, 2000; Roth \& O'Donnell, 1996). From the agency theory perspective, the extent of control parent firms exert over subsidiaries is a key dimension since agency theory is about "the optimal structuring of control relationships" to manage uncertainty stemming from the difficulties in verifying the claims from agents (Eisenhardt, 1989: 63). Following our argument that ownership modes differ in their exposure to uncertainty, we suggest that this research needs to control for the type of ownership mode as the ownership mode determines the contractual relationship within which the parent firm (i.e., the principal) and the foreign subsidiary (i.e., the agent) is embedded in.

Our results provide strong support for the necessity of a simultaneous analysis of external and internal uncertainty to capture the full effect of cultural distance. Therefore, our findings may also help to resolve the "cultural distance paradox" (Brouthers \& Brouthers, 2001; O’Grady \& Lane, 1996) in IB literature. In particular, our results suggest that often contradictory empirical evidence regarding the relationship between 
cultural distance and control may be explained not only by conceptual and methodological shortcomings of the cultural distance constructs (Shenkar, 2001), but also by a failure to control for the type of ownership mode.

\section{Limitations and future research}

As with every study, this one has several limitations as well. First, our dependent variable only captures the extent and focus of control as we define control as the actual extent of decision-making that takes place at the parent firm. However, we did not include organizational control mechanisms such as behavioral or social control suggested in the literature (Chang \& Taylor, 1999; Eisenhardt, 1989; Ouchi \& Maguire, 1975). Geringer and Hebert (1989), however, suggest that the three dimensions (extent, focus, and mechanisms) are complementary and interdependent and that is the reason why we excluded mechanisms of control from our analyses. Prior research has nevertheless argued that nationality or cultural distance influences the mechanisms of control exerted over foreign subsidiaries (Chang \& Taylor, 1999; Egelhoff, 1984; Hedlund, 1981; Lincoln \& Kalleberg, 1990; Ouchi, 1981; Pugh, 1998). Therefore, future studies should use a more fine-grained measure of control to account for different control types, which may address uncertainty stemming from cultural distance.

Second, we focused on foreign subsidiaries in one country, the PRC. This approach helps to keep one part of the cultural distance equation constant, but at the same time may lead to range restriction in our cultural distance variable. In other words, our results are specific to the context of China and thus it is not sure whether they are transferrable to other context (e.g., HQ-subsidiary relationships in developed countries). Moreover, given that we only have 13 home countries in our sample, the variance in our cultural distance measure is limited. Certainly, adding more home countries would loosen the range restriction and increase the variance in our measure. However, since range restriction decreases statistical power, our results may yield a conservative estimate of the effects of cultural distance on the extent of control. Nevertheless, future research should include a broader geographic sample to address this potential shortcoming. In addition, the size of both parent firms and subsidiaries in our sample was relatively large. Larger firms have more experience and resources to deal with external and internal uncertainty stemming from cultural distance and thus may lead to different levels of control. In order to enhance our understanding, future studies should verify whether cultural distance influences the extent of control small and medium enterprises (SMEs) exert over their foreign subsidiaries in a similar way.

Third, from the results of our study we are unable to draw any performance implications. Nevertheless, it would be interesting to analyze how strategic matches/ mismatches from the perspective of agency theory influence performance outcomes. Brouthers (2002), Brouthers et al. (2003), and Brouthers and Nakos (2004), for instance, have conducted research analyzing possible performance outcomes of similar strategic matches/mismatches with regard to entry mode choices. Future studies could thus adopt their approach and analyze how firms make decisions about the extent of control over their subsidiaries and how these decisions affect performance.

Fourth, with regard to IJVs, our focus was on control associated with the foreign parents. However, IJVs may also be exposed to control pressures coming from a 
Chinese partner, and future research may explore an interface of foreign and Chinese partners in terms of their control priorities in IJVs. Furthermore, we only focused on the ownership mode of the subsidiary distinguishing between IJVs and WoS, but did not integrate other decisions at the point of entry into our analysis such as the type of establishment mode (Brouthers \& Hennart, 2007). Future studies may thus use a more comprehensive measure of internationalization to account for a broader range of entry decisions and also account for different levels of equity ownership in an IJV (e.g., 50:50 or the Western HQ only holding a minority of shares).

Fifth, it seems reasonable to argue that firms confronted with information asymmetry stemming from cultural distance try to develop and implement managerial techniques to reduce or overcome the differences. While we are not able to assess such approaches, it is arguably a promising path for future researche to hypothesize on and test how companies try to reduce such asymmetries. Further, this may address the questions whether the achieved degree of control by HQ matches the intended degree of control. Future research in this direction may, for example, include testing if and how expatriates are able to reduce asymmetries or if companies using specific management information systems may be able to address this issue. In addition, it would be interesting to see how the relationship reacts to the development of trust between HQ management and subsidiary managers. We recommend future studies to venture deeper into this relationship.

Finally, another limitation relates to the measurement of variables, their subjective evaluation by a single firm representative, and the possibility of common method bias on the level of controls. In addition, although we relied on scales that have been used in other research, few of these scales have been designed for a cross-cultural research framework.

\section{Conclusion}

Building on principal agent theory, our study indicates that it is crucial to clearly distinguish between ownership rights, that is, the level of internalization within the Williamson's (1973) market-hierarchy continuum, and the actual extent of control exerted over foreign subsidiaries. The extent of control does not only depend on the generation and contribution of firm-specific assets or the type of mandate they develop within the global MNC network, but also on the type of ownership mode (IJVs/WoS) as these equity arrangements are subject to different types of agency conflicts. Finally and most importantly, agency conflicts in foreign subsidiaries are far from being universal. They are severely influenced by cultural differences between the home and host country and related to that external and internal uncertainty. Overall, our study presents a novel approach to questions of exerted control between HQ and subsidiaries and provides important guidance for future research in IB.

Acknowledgments Open access funding provided by Vienna University of Economics and Business (WU).

Open Access This article is distributed under the terms of the Creative Commons Attribution 4.0 International License (http://creativecommons.org/licenses/by/4.0/), which permits unrestricted use, distribution, and reproduction in any medium, provided you give appropriate credit to the original author(s) and the source, provide a link to the Creative Commons license, and indicate if changes were made. 


\section{References}

Agarwal, S. 1994. Socio-cultural distance and the choice of joint ventures: A contingency Perspective. Journal of International Marketing, 2(2): 63-80.

Agarwal, S., \& Ramaswami, S. N. 1992. Choice of foreign market entry mode: Impact of ownership, location and internalization factors. Journal of International Business Studies, 23(1): 1-27.

Aguinis, H. 1995. Statistical power problems with moderated multiple regression in management research. Journal of Management, 21(6): 1141-1158.

Aiken, L. S., \& West, S. G. 1991. Multiple regression: Testing and interpreting interactions. Thousand Oaks: Sage.

Anderson, E., \& Gatignon, H. 1986. Modes of foreign entry: A transaction cost analysis and propositions. Journal of International Business Studies, 17(3): 1-26.

Andersson, U., \& Forsgren, M. 1996. Subsidiary embeddedness and control in the multinational corporation. International Business Review, 5(5): 487-508.

Armstrong, J. S., \& Overton, T. S. 1977. Estimating nonresponse bias in mail surveys. Journal of Marketing Research, 14(3): 396-402.

Arthurs, J. D., Hoskisson, R. E., Busenitz, L. W., \& Johnson, R. A. 2008. Managerial agents watching other agents: Multiple agency conflicts regarding underpricing in IPO firms. Academy of Management Journal, 51(2): 277-294.

Barkema, H. G., Bell, J. H. J., \& Pennings, J. M. 1996. Foreign entry, cultural barriers, and learning. Strategic Management Journal, 17(2): 151-166.

Barkema, H. G., \& Vermeulen, F. 1997. What differences in the cultural backgrounds of partners are detrimental for international joint ventures?. Journal of International Business Studies, 28(4): 845-864.

Becker, T. E. 2005. Potential problems in the statistical control of variables in organizational research: A qualitative analysis with recommendations. Organizational Research Methods, 8(3): 274-289.

Benito, G. R. G., \& Gripsrud, G. 1992. The expansion of foreign direct investments: Discrete rational location choices or a cultural learning process?. Journal of International Business Studies, 23(3): 461-476.

Berry, H., Guillén, M. F., \& Nan, Z. 2010. An institutional approach to cross-national distance. Journal of International Business Studies, 41(9): 1460-1480.

Birkinshaw, J., Hood, N., \& Jonsson, S. 1998. Building firm-specific advantages in multinational corporations: The role of subsidiary initiative. Strategic Management Journal, 19(3): 221-241.

Birkinshaw, J. M., \& Morrison, A. J. 1995. Configurations of strategy and structure in subsidiaries of multinational corporations. Journal of International Business Studies, 26(4): 729-753.

Brenner, B., \& Ambos, B. 2013. A question of legitimacy? A dynamic perspective on multinational firm control. Organization Science, 24(3): 773-795.

Brislin, R. W. 1970. Back-translation for cross-cultural research. Journal of Cross-Cultural Psychology, 1(3): 185-216.

Brouthers, K. D. 2002. Institutional, cultural and transaction cost influences on entry mode choice and performance. Journal of International Business Studies, 33(2): 203-221.

Brouthers, K. D., \& Brouthers, L. E. 2001. Explaining the national cultural distance paradox. Journal of International Business Studies, 32(1): 177-189.

Brouthers, K. D., \& Brouthers, L. E. 2003. Why service and manufacturing entry mode choices differ: The influence of transaction cost factors, risk and trust. Journal of Management Studies, 40(5): 1179-1204.

Brouthers, K. D., Brouthers, L. E., \& Werner, S. 2003. Transaction cost-enhanced entry mode choices and firm performance. Strategic Management Journal, 24(12): 1239-1248.

Brouthers, K. D., \& Hennart, J.-F. 2007. Boundaries of the firm: Insights from international entry mode research. Journal of Management, 33(3): 395-425.

Brouthers, K. D., \& Nakos, G. 2004. SME entry mode choice and performance: A transaction cost perspective. Entrepreneurship: Theory and Practice, 28(3): 229-247.

Bruton, G. D., Ahlstrom, D., \& Li, H.-L. 2010a. Institutional theory and entrepreneurship: Where are we now and where do we need to move in the future?. Entrepreneurship: Theory and Practice, 34(3): 421-440.

Bruton, G. D., Filatotchev, I., Chahine, S., \& Wright, M. 2010b. Governance, ownership structure, and performance of IPO firms: The impact of different types of private equity investors and institutional environments. Strategic Management Journal, 31(5): 491-509.

Campbell, J. T., Eden, L., \& Miller, S. R. 2012. Multinationals and corporate social responsibility in host countries: Does distance matter?. Journal of International Business Studies, 43(1): 84-106.

Cassiman, B., \& Golovko, E. 2011. Innovation and internationalization through exports. Journal of International Business Studies, 42(1): 56-75. 
Chan, C. M., \& Makino, S. 2007. Legitimacy and multi-level institutional environments: Implications for foreign subsidiary ownership structure. Journal of International Business Studies, 38(4): 621-638.

Chang, E., \& Taylor, M. S. 1999. Control in multinational corporations (MNCs): The case of Korean manufacturing subsidiaries. Journal of Management, 25(4): 541-565.

Chang, S.-J., Chung, J., \& Moon, J. J. 2013. When do wholly owned subsidiaries perform better than joint ventures?. Strategic Management Journal, 34(3): 317-337.

Chang, S.-J., \& Rosenzweig, P. M. 2001. The choice of entry mode in sequential foreign direct investment. Strategic Management Journal, 22(8): 747-776.

Cho, K. R., \& Padmanabhan, P. 2005. Revisiting the role of cultural distance in MNC's foreign ownership mode choice: The moderating effect of experience attributes. International Business Review, 14(3): 307324.

Cleeve, E. 1997. The motives for joint ventures: A transaction costs analysis of Japanese MNEs in the UK. Scottish Journal of Political Economy, 44(1): 31-43.

Combs, J. G., \& Ketchen, D. J., Jr. 1999. Explaining interfirm cooperation and performance: Toward a reconciliation of predictions from the resource-based view and organizational economics. Strategic Management Journal, 20(9): 867-888.

Cray, D. 1984. Control and coordination in multinational corporations. Journal of International Business Studies, 15(2): 85-98.

Davis, P. S., Desai, A. B., \& Francis, J. D. 2000. Mode of international entry: An isomorphism perspective. Journal of International Business Studies, 31(2): 239-258.

Demirbag, M., Glaister, K. W., \& Tatoglu, E. 2007. Institutional and transaction cost influences on MNEs' ownership strategies of their affiliates: Evidence from an emerging market. Journal of World Business, 42(4): 418-434.

Dow, D., \& Ferencikova, S. 2010. More than just national cultural distance: Testing new distance scales on FDI in Slovakia. International Business Review, 19(1): 46-58.

Doz, Y. L., \& Prahalad, C. K. 1981. Headquarters influence and strategic control in MNCs. Sloan Management Review, 23(1): 15-29.

Doz, Y., \& Prahalad, C. K. 1984. Patterns of strategic control within multinational corporations. Journal of International Business Studies, 15(2): 55-72.

Drogendijk, R., \& Slangen, A. 2006. Hofstede, Schwartz, or managerial perceptions? The effects of different cultural distance measures on establishment mode choices by multinational enterprises. International Business Review, 15(4): 361-380.

Edwards, R., Ahmad, A., \& Moss, S. 2002. Subsidiary autonomy: The case of multinational subsidiaries in Malaysia. Journal of International Business Studies, 33(1): 183-191.

Egelhoff, W. G. 1984. Patterns of control in US, UK, and European multinational corporations. Journal of International Business Studies, 15(2): 73-83.

Eisenhardt, K. M. 1989. Agency theory: An assessment and review. Academy of Management Review, 14(1): 57-74.

Filatotchev, I., \& Wright, M. 2011. Agency perspectives on corporate governance of multinational enterprises. Journal of Management Studies, 48(2): 471-486.

Fladmoe-Lindquist, K., \& Jacque, L. L. 1995. Control modes in international service operations: The propensity to franchise. Management Science, 41(7): 1238-1250.

Fratianni, M., \& Chang Hoon, O. 2009. Expanding RTAs, trade flows, and the multinational enterprise. Journal of International Business Studies, 40(7): 1206-1227.

Garnier, G. H. 1982. Context and decision making autonomy in the foreign affiliates of U.S. multinational corporations. Academy of Management Journal, 25(4): 893-908.

Gates, S. R., \& Egelhoff, W. G. 1986. Centralization in headquarters-subsidiary relationships. Journal of International Business Studies, 17(2): 71-92.

Gatignon, H., \& Anderson, E. 1988. The multinational corporation's degree of control over foreign subsidiaries: An empirical test of a transaction cost explanation. Journal of Law, Economics and Organization, 4(2): 305-336.

Gaur, A. S., \& Lu, J. W. 2007. Ownership strategies and survival of foreign subsidiaries: Impacts of institutional distance and experience. Journal of Management, 33(1): 84-110.

Geringer, J. M., \& Hebert, L. 1989. Control and performance of international joint ventures. Journal of International Business Studies, 20(2): 235-254.

Ghoshal, S., \& Moran, P. 1996. Bad for practice: A critique of the transaction cost theory. Academy of Management Review, 21(1): 13-47.

Gu, X. S., \& Rosenbaum, P. R. 1992. Comparison of multivariate matching methods: Structures, distances, and algorithms. Journal of Computational and Graphical Statistics, 2(4): 405-420. 
Hamilton, R. D., III, \& Kashlak, R. J. 1999. National influences on multinational corporation control system selection. Management International Review, 39(2): 167-189.

Harzing, A. W. K. 1999. Managing the multinationals: An international study of control mechanisms. Cheltenham: Edward Elgar.

Hedlund, G. 1981. Autonomy of subsidiaries and formalization of headquarters-subsidiary relationships in Swedish MNCs. In L. Otterbeck (Ed.). The management of headquarter-subsidiary relationships in multinational corporations. Aldershot: Gower.

Hennart, J.-F. 1991. The transaction costs theory of joint ventures: An empirical study of Japanese subsidiaries in the United States. Management Science, 37(4): 483-497.

Hennart, J.-F., \& Larimo, J. 1998. The impact of culture on the strategy of multinational enterprises: Does national origin affect ownership decisions?. Journal of International Business Studies, 29(3): 515-538.

Hennart, J.-F., \& Zeng, M. 2002. Cross-cultural differences and joint venture longevity. Journal of International Business Studies, 33(4): 699-716.

Hill, C. W. L., Hwang, P., \& Kim, W. C. 1990. An eclectic theory of the choice of international entry mode. Strategic Management Journal, 11(2): 117-128.

Hofstede, G. 1980. Culture's consequences: International differences in work-related values. Beverly Hills: Sage.

Hofstede, G. 2001. Culture's consequences: Comparing values, behaviors, institutions, and organizations across nations, 2nd ed. Thousand Oaks: Sage.

Javidan, M., House, R. J., Dorfman, P. W., Hanges, P. J., \& de Luque, M. S. 2006. Conceptualizing and measuring cultures and their consequences: A comparative review of GLOBE's and Hofstede's approaches. Journal of International Business Studies, 37(6): 897-914.

Jensen, M., \& Meckling, W. 1976. Theory of the firm: Managerial behavior, agency costs, and ownership structure. Journal of Financial Economics, 3(4): 305-360.

Jensen, R., \& Szulanski, G. 2004. Stickiness and the adaptation of organizational practices in cross-border knowledge transfers. Journal of International Business Studies, 35(6): 508-523.

Johnson, J. L., Cullen, J. B., Sakano, T., \& Bronson, J. W. 2001. Drivers and outcomes of parent company intervention in IJV management: A cross-cultural comparison. Journal of Business Research, 52(1): 35-49.

Kim, C. W., \& Hwang, P. 1992. Global strategy and multinationals' entry mode choice. Journal of International Business Studies, 23(1): 29-53.

Kim, Y., \& Gray, S. 2009. An assessment of alternative empirical measures of cultural distance: Evidence from the Republic of Korea. Asia Pacific Journal of Management, 26(1): 55-74.

Kobrin, S. J. 1988. Expatriate reduction and strategic control in American multinational corporations. Human Resource Management, 27(1): 63-75.

Kogut, B., \& Singh, H. 1988. The effect of national culture on the choice of entry mode. Journal of International Business Studies, 19(3): 411-432.

Lee, S.-H., Shenkar, O., \& Li, J. 2008. Cultural distance, investment flow, and control in cross-border cooperation. Strategic Management Journal, 29(10): 1117-1125.

Lincoln, J. R., \& Kalleberg, A. L. 1990. Culture, control and commitment: A study of work organization and work attitudes in the United States and Japan. Cambridge: Cambridge University Press.

Lu, J. W., \& Hébert, L. 2005. Equity control and the survival of international joint ventures: A contingency approach. Journal of Business Research, 58(6): 736-745.

Luo, Y., Shenkar, O., \& Nyaw, M.-K. 2001. A dual parent perspective on control and performance in international joint ventures: Lessons from a developing economy. Journal of International Business Studies, 32(1): 41-58.

Magnusson, P., Wilson, R. T., Zdravkovic, S., Joyce Xin, Z., \& Westjohn, S. A. 2008. Breaking through the cultural clutter. International Marketing Review, 25(2): 183-201.

Makhija, M. V., Kim, K., \& Williamson, S. D. 1997. Measuring globalization of industries using a national industry approach: Empirical evidence across five countries and over time. Journal of International Business Studies, 28(4): 679-710.

Martinez, J. I., \& Jarillo, J. C. 1991. Coordination demands of international strategies. Journal of International Business Studies, 22(3): 429-444.

Meschi, P.-X., \& Riccio, E. L. 2008. Country risk, national cultural differences between partners and survival of international joint ventures in Brazil. International Business Review, 17(3): 250-266.

Mjoen, H., \& Tallman, S. 1997. Control and performance in international joint ventures. Organization Science, 8(3): 257-274.

MOFCOM. 2010. Foreign investment department of the Chinese Ministry of Commerce: Statistics of Cumulative FDI by Form as of 2008. http://www.fdi.gov.cn/pub/FDI_EN/Statistics/ AnnualStatisticsData/AnnualFDIData/FDIStatistics,2010/t20120207_140888.htm, Accessed Dec. 20, 2010. 
Morosini, P., Shane, S., \& Singh, H. 1998. National cultural distance and cross-border acquisition performance. Journal of International Business Studies, 29(1): 137-158.

O’Donnell, S. W. 2000. Managing foreign subsidiaries: Agents of headquarters, or an interdependent network?. Strategic Management Journal, 21(5): 525-548.

O'Grady, S., \& Lane, H. W. 1996. The psychic distance paradox. Journal of International Business Studies, 27: 309-333.

Ott, U. F. 2005. International joint ventures: A common agency problem. Global Business and Economics Review, 2(1): 67-84.

Ouchi, W. G. 1981. Theory Z: How American business can meet the Japanese challenge. Reading: AddisonWesley.

Ouchi, W. G., \& Maguire, M. A. 1975. Organizational control: Two functions. Administrative Science Quarterly, 20(4): 559-569.

Padmanabhan, P., \& Cho, K. R. 1996. Ownership strategy for a foreign affiliate: An empirical investigation of Japanese firms. Management International Review, 36(1): 45-65.

Podsakoff, P. M., MacKenzie, S. B., Jeong-Yeon, L., \& Podsakoff, N. P. 2003. Common method biases in behavioral research: A critical review of the literature and recommended remedies. Journal of Applied Psychology, 88(5): 879-903.

Puck, J. F., Holtbrügge, D., \& Mohr, A. T. 2009. Beyond entry mode choice: Explaining the conversion of joint ventures into wholly owned subsidiaries in the People's Republic of China. Journal of International Business Studies, 40(3): 388-404.

Pugh, D. S. 1998. Classic research in management series: The Aston programme-Volumes I and II. Aldershot: Ashgate Publishing.

Reeb, D., Sakakibara, M., \& Mahmood, I. P. 2012. From the editors: Endogeneity in international business research. Journal of International Business Studies, 43(3): 211-218.

Reuer, J. J., \& Miller, K. D. 1997. Agency costs and the performance implications of international joint venture internalization. Strategic Management Journal, 18(6): 425-438.

Root, F. R. 1987. Entry strategies for international markets. Lexington: DC Heath and Company.

Rosenbaum, P. R., \& Rubin, D. E. 1983. The central role of the propensity score in observational studies for causal effects. Biometrika, 70(1): 41-55.

Roth, K., \& Morrison, A. J. 1992. Implementing global strategy: Characteristics of global subsidiary mandates. Journal of International Business Studies, 23(4): 715-735.

Roth, K., \& O’Donnell, S. 1996. Foreign subsidiary compensation strategy: An agency theory perspective. Academy of Management Journal, 39(3): 678-703.

Rubin, D. B. 1979. Using multivariate matched sampling and regression adjustment to control bias in observational studies. Journal of the American Statistical Association, 74(366a): 318-328.

Salomon, R., \& Wu, Z. 2012. Institutional distance and local isomorphism strategy. Journal of International Business Studies, 43(4): 343-367.

Schafer, J. L., \& Kang, J. 2008. Average causal effects from nonrandomized studies: A practical guide and simulated example. Psychological Methods, 13(4): 279-313.

Schwens, C., Eiche, J., \& Kabst, R. 2011. The moderating impact of informal institutional distance and formal institutional risk on SME entry mode choice. Journal of Management Studies, 48(2): 330-351.

Scott, W. R. 1995. Institutions and organizations. Thousand Oaks: Sage.

Shenkar, O. 2001. Cultural distance revisited: Towards a more rigorous conceptualization and measurement of cultural differences. Journal of International Business Studies, 32(3): 519-535.

Sitkin, S. B., \& George, E. 2005. Managerial trust-building through the use of legitimating formal and informal control mechanisms. International Sociology, 20(3): 307-338.

Slangen, A. H. L., \& van Tulder, R. J. M. 2009. Cultural distance, political risk, or governance quality? Towards a more accurate conceptualization and measurement of external uncertainty in foreign entry mode research. International Business Review, 18(3): 276-291.

Sohn, J. H. D. 1994. Social knowledge as a control system: A proposition and evidence from the Japanese FDI behavior. Journal of International Business Studies, 25(2): 295-324.

Stuart, E. A. 2010. Matching methods for causal inference: A review and a look forward. Statistical Science, 25(1): 1-21.

Taggart, J., \& Hood, N. 1999. Determinants of autonomy in multi-national corporation subsidiaries. European Management Journal, 17(2): 226-236.

Thoemmes, F. J., \& Kim, E. S. 2011. A systematic review of propensity score methods in the social sciences. Multivariate Behavioral Research, 46(1): 90-118.

UNCTAD. 2011. Inward and outward foreign direct investment flows, annual, 1970-2010. http://unctadstat. unctad.org, Accessed Feb. 22, 2012. 
Van den Bulcke, D., \& Halsberghe, E. 1984. Employment decision-making in multinational enterprises: Survey results from Belgium. Geneva: International Labour Office.

Vermeulen, F., \& Barkema, H. 2001. Learning through acquisitions. Academy of Management Journal, 44(3): $457-476$.

Wilkinson, T. J., Peng, G. Z., Brouthers, L. E., \& Beamish, P. W. 2008. The diminishing effect of cultural distance on subsidiary control. Journal of International Management, 14(2): 93-107.

Williamson, O. E. 1973. Markets and hierarchies: Some elementary considerations. American Economic Review, 63(2): 316-325.

Williamson, O. E. 1991. Comparative economic organization: The analysis of discrete structural alternatives. Administrative Science Quarterly, 36(2): 269-296.

Xiao, G. 2004. People's Republic of China's round-tripping FDI: Scale, causes, and implications. http://www. adbi.org/files/2004.dp7.foreign.direct.investment.people.rep.china.implications.pdf, Accessed Mar. 5, 2006.

Xu, D., \& Shenkar, O. 2002. Institutional distance and the multinational enterprise. Academy of Management Review, 27(4): 608-618.

Yamin, M., \& Golesorkhi, S. 2010. Cultural distance and the pattern of equity ownership structure in international joint ventures. International Business Review, 19(5): 457-467.

Yan, A., \& Gray, B. 2001a. Antecedents and effects of parent control in international joint ventures. Journal of Management Studies, 38(3): 393-416.

Yan, A., \& Gray, B. 2001b. Negotiating control and achieving performance in international joint ventures: A conceptual model. Journal of International Management, 7(4): 295-315.

Yiu, D., \& Makino, S. 2002. The choice between joint venture and wholly owned subsidiary: An institutional perspective. Organization Science, 13(6): 667-683.

Young, S., Hood, N., \& Hamill, J. 1985. Decision-making in foreign-owned multinational subsidiaries in the United Kingdom. Geneva: Geneva International Labour Office.

Zhao, H., Luo, Y., \& Suh, T. 2004. Transaction cost determinants and ownership-based entry mode choice: A meta-analytical review. Journal of International Business Studies, 35(6): 524-544.

Jonas Puck ( $\mathrm{PhD}$, Nuremberg University) is Head of the Institute for International Business and Full Professor at WU Vienna. His current research interests lie in the overlaps of global strategy, finance, and political science. Jonas serves on the Editorial Boards of the Journal of International Business Studies, Long Range Planning, European Management Journal, and Journal of World Business. His research has been published in journals such as the Journal of International Business Studies, Journal of Management Studies, Journal of World Business, Long Range Planning, Management International Review, and Human Resource Management (US), among others. In addition, he is editor or author of five books and numerous book chapters.

Markus K. Hödl (PhD, WU Vienna University of Economics and Business) works as an inhouse consultant for a large international packaging and paper company. He holds a doctorate in international business from WU Vienna University of Economics and Business. His research focuses on headquarters-subsidiary relations and investments in emerging markets.

Igor Filatotchev ( $\mathrm{PhD}$, Institute of World Economy and International Relations) is professor of corporate governance and strategy at Cass Business School, City University London, and a visiting professor at Vienna University of Economics and Business. His research interests are focused on corporate governance effects on entrepreneurship and strategic decisions; sociology of capital markets. He has published more than 120 refereed academic papers, in addition to numerous books and book chapters, in the fields of corporate governance, entrepreneurship, and strategy including publications in the Academy of Management Journal, Academy of Management Perspectives, Strategic Management Journal, Journal of International Business Studies, Organization Science, California Management Review, Journal of Management Studies, and Journal of Management. Most recently he coedited "The Oxford Handbook of Corporate Governance" (2013). He is a General Editor of Journal of Management Studies. Before joining Journal of Management Studies editorial team he was an Associate Editor of Corporate Governance: An International Review. 
Hans-Georg Wolff ( $\mathrm{PhD}$, University of Erlangen-Nuremberg) is a professor of organizational and economic psychology at the University of Cologne, Germany. He obtained a diploma in psychology at the University of Giessen and received his PhD (2004) and his Habilitation (2010) from the School of Business and Economics at the University of Erlangen-Nuremberg. His research focuses on organizational behavior, in particular social relations (networking) at work, career success, decision making, and also research methods.

Benjamin Bader (PhD, University of Hamburg) is professor of strategic management and organization at the Leuphana University of Lüneburg. His research interests include international (human resource) management and strategy, with a special emphasis on expatriate management. He is a Strategic Advisor to the RES Forum and his work has been published in a number of journals such as the International Business Review, International Journal of Human Resource Management, and Journal of International Management, among others. 